\title{
Terör Saldırılarının Irak ve Suriye'deki İnanç Turizmi Kapsamında Önemli Olan Yapılara (Doğal, Tarihi, Kültürel veya Kutsal Yapılara) Verdiği Tahribatın İncelenmesi ve Siyasi Otoritelerin İzlediği Yol
}

\author{
Yüksek Lisans Öğrencisi Oğuz ÇAM \\ Kastamonu Üniversitesi Sosyal Bilimler Enstitüsü \\ oguzcam911@gmail.com \\ https://orcid.org/0000-0003-3222-3367 \\ Dr. Öğr. Üyesi Muharrem AVCI \\ Kastamonu Üniversitesi Turizm Fakültesi \\ mavci@kastamonu.edu.tr \\ https://orcid.org/0000-0002-0264-1181 \\ https://doi.org/10.37847/tdtad.734234
}

\section{Özet}

Siyasi otoritelerin Irak ve Suriye ülkelerine karşı nasıl bir davranışta bulunduğu ve terör, savaş, çatışma gibi olayların kutsal yapılara verdiği zararın değerlendirilmesi amacıyla bu tür bir çalışma başlatılmış bulunmaktadır. Bu çalışma terör saldırılarının altındaki sorunları belirleme, çözüm önerileri belirtme, siyasi gelişmelerin inanç turizmine yansittığ olumlu-olumsuz yönleri saptama açısından önem arz etmektedir. İnsanların bilgilendirilmemesi, bilinçlendirilmemesi, önemli değerlerin korunmaması ya da korunamaması, siyasi otoritelerin uyguladığı strateji ve planları göz önünde bulundurarak kamuoyunu istenilen düzeyde etkili bir şekilde aydınlatılamaması araştırmanın problemini ortaya koymaktadır. Bu çalışmanın evreni; Ortadoğu Bölgesi, örneklemi ise; Irak ve Suriye ülkeleridir. Bu çalışmada nitel araştırma yöntemi kullanılmakta ve doküman analizi tekniği ile değerlendirilmektedir. Sonuç olarak; Irak ve Suriye'de toprak bütünlüğü büyük risk altında olmaktadır. Toprakları üzerinde terör saldırıları, iç savaş, çatışmalar, siyasi istikrarsızlık, can ve mal kayıpları, türlü işkenceler ve ülke içerisinden dışarıya göçler yaşanmaktadır. Bu bölgelerde önemli yapıların (dini, tarihi, kültürel ve benzeri yapılar) iç savaş ve terör olayları saldırıları esnasında tahribata uğramaktadır.

Anahtar Kelimeler: Irak, Suriye, Kültürel Miras, Savaş ve Tahribat, İnanç Turizmi.

\section{Investigation of the Destruction Attacked by Terrorist Attacks to the Structures (Natural, Historical, Cultural or Sacred Structures) in the Scope of Faith Tourism in Iraq and Syria, and the Path of Political Authorities}

Abstract

Such a study has been initiated in order to evaluate the behavior of political authorities against Iraqi and Syrian countries and to evaluate the damage caused by terrorism, war, conflict to sacred structures. It is important in terms of identifying problems under terrorist attacks, specifying solutions, and identifying positive and negative aspects that political developments reflect on faith tourism. The fact that people are not informed, not raised, or that important values are not preserved or protected, and that they cannot effectively enlighten the public at the desired level by considering 
the strategies and plans implemented by the political authorities reveals the problem of the research. The universe of this study; Middle East Region, sample is; Iraq and Syria are countries. In this study, qualitative research method is used and evaluated with document analysis technique. As a result; Territorial integrity is at great risk in Iraq and Syria. Terrorist attacks, civil wars, conflicts, political instability, loss of life and property, all kinds of torture and migration from the country are experienced on its territory. In these regions, important structures (religious, historical, cultural and similar structures) are damaged during the attacks of civil war and terrorist events.

Keywords: Iraq, Syria, Cultural Heritage, War and Destruction, Faith Tourism.

\section{Giriş}

Terör gruplarının kutsal yapılara zarar vermesi, siyasi gelişmelerden doğan olumsuz neticeler, siyasi otoritelerin olaylar karşısında takındığ 1 tavır, yıldırarak, korkutarak, sindirerek insanları bir şeylere mecbur ettirme insan hayatını çok kötü etkilemektedir. Ulusal ve uluslararası platformlarda terör konusuna ilişkin toplantılara, müzakerelere netlik ve etkinlik kazandırılması gerekmektedir. Terörün bulunduğu bölgelerde inanç turizmi faaliyetlerine katılmak mümkün olmamaktadır. En önemli sorun ise; insanların yaşama hakkı ellerinden alınabilmektedir. Terörün olduğu yerlerde kargaşa hüküm sürmektedir. Terörün ortadan kaldırılması ve insanların bilinçlendirilmesi önem arz etmektedir. Irak ve Suriye'de gerçekleşen terör olaylarına daha çok yoğunlaşılarak, insanların dayanışma, yardımlaşma ve birlik halinde olması gerekmektedir.

Irak ve Suriye Ortadoğu Bölgesinde yer alan iki ülkedir. Bu iki ülkenin torakları, yeraltı ve yer üstü kaynakları bakımından zengin olmaktadır ve önemli yapıları (kültürel, dini, tarihi ve kutsal mekânları) bünyesinde barındırmaktadır. Gerek ülke içerisinde gerek ise ülke dışarısında Irak ve Suriye hakkında birçok olumsuz gelişmelerin yaşandığı görülmektedir. Bu iki ülkenin savaş dair yeterince siyasi otoriteler tarafından bilinçlendirilmediği görülmektedir. Buradaki topraklardaki önemli yapılar (kültürel, dini, tarihi açıdan önem arz eden yapılar) yalnız o ülkenin değil, bütün insanlığın ortak değerleri arasında bulunmaktadır. Tahrip edilmesine izin verilmemesi, korunması ile ilgili çalışmaların gerçekleştirilmesi gerekmektedir. Bu anlamda siyasi otoritelerin el ele verip bu sorun hakkındaki görüşleri ortak bir noktada buluşup, hem terörün ortadan kalkması hem de kültürel değerlerin muhafaza edilmesi konusu itibarıyla bilgilendirmek, bilinçlendirmek, kaybolan/kaybolacak değerleri göz önüne sermek hayati anlamda önem taşımaktadır. Kültürel değerleri muhafaza edilmemiş bir millet zamanla öz benliklerini kaybedeceklerdir. Özetle bu çalışma kapsamında insanların bilgilendirilmemesi, bilinçlendirilmemesi, önemli değerlerin korunmaması ya da korunamaması, siyasi otoritelerin uyguladığ1 strateji ve planları göz önünde bulundurarak kamuoyunu istenilen düzeyde etkili bir şekilde aydınlatılamaması araştırmanın problemini ortaya koymaktadır.

Güvenlik, insanların rahat ve huzur içinde yaşayabilmesi için dikkat edilmesi gereken çok önemli bir unsur olmaktadır. Sosyal, ekonomik, psikolojik, çevresel ve beşeri açılardan yönünden terör olayları ile ilgili bir bağlantı bulunması mümkün olmaktadır. Çünkü her davranışın bir nedeni olmaktadır. Günümüzün en önemli problemleri arasında yer alan iç savaşlar, çatışmalar, terör olayları, saldırılar ve benzeri gibi meydana gelebilen olumsuz durumlar insanların hayatlarında unutamayacağı izler bırakabilmekte, mal kaybı veya can kaybına neden olabilmektedir. Terörizm insanların en büyük belalarından biri olmaktadır. Terör grupları insanları yıldırmayı, tahrip etmeyi ve doğal, tarihi veya kültürel çevrelere zarar vermeyi amaç edinmektedir. Kutsal yapılar, inanç turizmi bağlamında çok önemli bir işlev üstlenmektedir. İnsanlara manevi bir hava solumasına yardımcı olmakta, inançlara 
yönelik vazifeleri yerine getirmeyi sağlamakta, hem bedenen hem de ruhen mutlu ve huzurlu bir hayat sürmek için katkı sağlamaktadır. Irak ve Suriye ülkeleri Ortadoğu Bölgesinde iç karışıklıkların, çatışmaların ve savaşların yoğunluk gösterdiği bir yer olarak dikkatleri üzerine çekmektedir. Siyasi otoritelerin Irak ve Suriye ülkelerine karşı nasıl bir davranışta bulunduğu ve terör, savaş, çatışma gibi olayların kutsal yapılara verdiği zararın değerlendirilmesi amacıyla bu tür bir çalışma başlatılmış bulunmaktadir.

$\mathrm{Bu}$ çalışma, terör ve turizm ile alakalı yapılacak çalışmalar kaynak teşkil etmektedir. Siyasi otoritelerin terör karşısında izlediği yol, strateji, hedefler hakkında insanlar daha çok bilgilendirilmiş olacak ve böylece bilinçlenme durumu oluşacak veya bilinçlenme düzeyi artacaktır. Turizm sektörünün en olumsuz etkileyen etmenler arasında güvenlik sorunu yer almaktadır. Terör saldırıları inanç turizmine de doğrudan olumsuz etki yaratmaktadır. İnanç turizmi destinasyonlarını tahrip etmeyi, sosyal, psikolojik, ekonomik, dini, ahlaki olarak da zarar vermeyi amaçlamaktadır. Terör saldırılarının altındaki sorunları belirleme, çözüm önerileri belirtme, siyasi gelişmelerin inanç turizmine yansıttığı olumlu-olumsuz yönleri saptama açısından önem arz etmektedir.

Terör insanların hayatında en büyük tehdit unsuru olarak bulunmaktadır. Turizm faaliyetlerinin gerçekleştirilmesi için güvenli bir ortama ihtiyaç olmaktadır. Terör saldırılarıyla birlikte insanlar kendilerini huzursuz ve mutsuz hissetmektedirler. Bu sorunların altındaki temel çıkış noktalarında sosyal, psikolojik, çevresel, dini görüşlerin olduğu dikkat çekmektedir. Günümüzde birçok yer işgale uğramakta, insanlara türlü türlü işkenceler edilmekte, özellikle de İslam dinini yanlış tanıtmaya yönelik birtakım tutum ve davranışlar sergilenmektedir. Dünyada Ortadoğu Bölgesi zaman geçtikçe böyle bir hale gelmiş bulunmaktadır. Irak ve Suriye ülkeleri, gerek yer altı ve yer üstü kaynaklarının sömürülmesi bakımından gerekse toprak bütünlüklerinin işgal edilmesi bakımından zor günler yaşamaktadır. Ülkelerin arasındaki anlaşmazlıklar, yaşanan olumsuz olaylar milletleri derinden etkilemektedir.

Terör, insanları, yıldırmak, sindirmek, korkutmak yoluyla onlara belirli davranış ve fikirleri benimsetme amaciyla tehdit etme veya kaba kuvvet kullanma eylemi olmaktadır (Bozdemir, 1981: 526; Şener, 2012: 3). Terörün tanımlanmasını içinde bulunduğumuz asra göre çevirmek gerektiğinde şu şekilde bir tanıma gitmek daha doğru olacaktır. Terör; "herhangi bir amaca ulaşmak için, sivillerin veya güvenlik görevlilerinin, propagandaya yönelik ses getirici eylemler ile öldürülmesidir" (Bal, 2006: 8) biçiminde tanımlanabilmektedir. Terör her şeyden evvel şiddet olgusunun bir çeşididir ve şiddet kavramıyla ilişkili olmaktadır (Özerkmen, 2004: 248).

Aşırı korku, dehşet manalarına karşılık gelen terör bir metot olarak kullanıldığında karşımıza terörizm çıkmaktadır (Kaya, 2005: 1). Terörizm siyasi gayeler için sistemli, örgütlü ve devamlı terör kullanmayı metot olarak benimseyen bir strateji anlayışı ve aynı anda bir harbin öğretisi olmaktadır (Bozdemir, 1981: 526; Şener, 2012: 5). Terörizmin başlıca maksadıysa, siyasi iktidarın yerine geçmeyi arzulayan güçlerin yıpratmak ve bu esnada sindirdikleri hedef kitleleri de sahipsiz kaldığı inancına yöneltmek amacıyla şiddet eylemlerinden faydalanmaktadır (Ünsal ve Keleş, 1982: 3; Şener, 2012: 5). Literatür incelemesinde; İnanç turizmi, Irak ve Suriye'deki terör saldırıları, bu saldırıların önemli yapılara verdiği zarar, siyasi otoritelerin izlediği yol gibi konulara değinilmiştir.

\section{Literatür İncelemesi}

Turizm sektörünün gelişmesi için, ülke ve devlet yönetiminin pek çok tedbir alması gerekmektedir. Bu sektörden oldukça yüksek oranlarda gelir elde edildiği için, terör eylemlerinde turistik alanların veya turistik tüketicilerin hedef alınması, terör saldırıları açısından, bir anlamda devletin hedef 
alınması olarak idrak edilebilmektedir. Bu sebeple, turizme sektörüne yapılan bütün saldırılar aslında devlete yöneltilmiş saldırı olarak kabul görmektedir (Oktayer, Susam ve Çak, 2007: 148).

Teröristler için turistik alanlar mantıklı hedefler içerisinde olmaktadır. Terörist eylemler, teröristlerin büyük oranda gizlenebildiği, transit geçiş noktalarında yabancı kişilerin yoğunluk gösterdiği alanlarda, daha basit bir şekilde yapılabilmektedir. Netice itibariyle turizm ve terörizm arasında belirli bir bağlantının var olduğunu dile getirmek mümkün olmaktadır (Şener, 2012: 55-56).

Richter (1983: 18-19)'e göre bazı ülkelerde ya da durumlarda turizm, turizmin gelişimini destekleyenler ya da karşı çıkan içerisinde çatışmalara sebep olabileceğini savunmaktadır. Turizmin, kültürel yozlaşma ve yerli sanayinin bozulmasında sorumlu olması fikrinin var olması, hatta turizmin gelişmesinin yerli halka yarar sağlamadığı algısı toplum içinde kutuplaşma ortaya çıkararak terörizm gibi şiddetli olaylara neden olabilmektedir (Richter ve Waugh 1986: 237).

İnanç turizmi dinler tarafından mukaddes mekânlara ziyaret gerçekleştirmek, dini törenlere ve toplantılara katılmak, hac gibi dinin vazifeleri yerine getirmek, ünlü ve mukaddes mabetleri görmek maksadı ile yapılan ve mühim boyutlara ulaşan yolculukların ve konaklamaların oluşturduğu bir turizm hareketi olmaktadır (Usta, 2008). Richards (2007) ise inanç turizmini, "uluslararası turizm literatüründe genel kabul gören biçimiyle, kutsal yerlerin, bu dinlere mensup turistlerce ziyaret edilmesine ilişkin faaliyetler bütünüdür" biçiminde açıklamaktadır.

İnanç turizmi, geçmiş zamanlarda olduğu gibi günümüzde de önemini korumayı sürdürmektedir. Eski zamanlar da insanların yaşamlarında mukaddes yeri ziyaret etme dinsel bir vecibe iken şimdi de aynı özelliğini muhafaza etmekte, insanın yaşamının bir parçasını oluşturmayı sürdürmektedir. İlk çağlardan bu yana insanların dünya görüşlerini ve yaşantılarını etkisi altına alan en mühim etmenlerden bir tanesi din olmaktadır. Din insanlığın ortak paydasını meydana getirmektedir. Dinler, insanlar arasında kardeşlik ihdasını ve barışı emretmektedir. Uygarlıkların buluşma noktasının merkezinde dinler yer almaktadır. İnsanlar için peygamber ve din büyüklerinin hayatlarını geçirdikleri, ibadet yaptıkları yerler ve mezarları her daim, bir dine üye olanlar için mukaddes yerler sayılmış ve ziyaret gerçekleştirilen yerler olmuştur (Kaynak, 2010: 125).

Mukaddes mekânlar, inanç turizminde ana kaynakları meydana getirmekte ve turizm ile inanç sistemleri arasında bir bağlantı oluşturmaktadır. Geçmişten günümüze mitolojik, tarihsel, dinsel hadiseler ve bunların ortaya çıktığı yerler tamamıyla değişme göstermiş olsa da, hala yoğun bir ilgi görmektedir ve insanlar için farklı turizm imkânları sunan yerler içerisinde yer almaktadır (Özgüç, 2011). Bu mekânlara gerçekleştirilen seyahatlerde dini değerlerin, duyguların ve inançların önemi çok büyük olmaktadır. Dünya üzerinde istisnaları olmakla beraber, pek çok toplulukta, kendi inandığ 1 dine mensup olsun ya da mensup olmasın, dini şahsiyetlere, mekânlara ve değerlere sayg1 gösterilir. Çeşitli inanışlara ve dinlere ait söylem ya da öğretilerde mukaddes mekânlara saygı göstermekten ve hoşgörüyle bakmaktan bahsetmektedir. Bu saygının bir gereği olarak da kişiler çoğunlukla mensubu olduğu dine ait mekânlara ziyaret gerçekleştirdikleri gibi farklı inanışlara ait olan mukaddes mekânlara da ziyaret gerçekleștirebilirler. Dini yapılar (cami, kilise, manastır, sinagog, tapınak), dini mekânlar (dini şahsiyetlerin dünyaya geldiği, yaşadığı ya da öldüğü yerler, izledikleri yollar, mukaddes topraklar, hac mekânı), dini karakterli törenler ve kutlamalar, festivaller, mukaddes eşyalar (dinlere ya da dini şahsiyetlere ait) inanç turizmi kapsamı içerisinde değerlendirilebilmektedir (Kervankıran ve Eryılmaz, 2017: 277).

Bir turizm varış yerinde yaşanan çatışmanın sona erdirilmesi ve gerilimin azaltılması, insanlar üzerinde güvenli ortam algısının oluşmasına yardımcı olabilecektir. Oluşan bu güvenlik algısı, o 
turizm varış yerinin turistler tarafından tercih edilmesinde mühim bir rol üstlenmektedir (Anson, 1999: 57; Çakıc1 vd., 2015: 649).

Turistlerin tatil yeri seçimlerini etkileyen pek çok etmen bulunmaktadır. Bunlardan birkaçı tatil yerlerinin sahip olduğu fiziki ve doğal şartlara dayalı etmenler iken (doğal çekicilikler, tarihi ve kültürel zenginlikler vb.), birkaçı da tatil yerinin sahip olduğu ekonomik, sosyal ve siyasi (savaş ortam1, terör hadiseleri, siyasi istikrar vb.) şartlara dayalı etmenler olmaktadır (Güvenek ve Alptekin, 2015). Savaş ortamı, terör hadiseleri, siyasi istikrarsızlık vb. gibi etmenlerin meydana gelme sıklığ ve şiddetinin yoğunluk gösterdiği yerlerde turist girişleri de önemli seviyede azalmaktadır (Emsen ve Değer, 2004). Turistler mutlu, huzurlu ve rahat bir tatil geçirmeyi arzu ettiklerinden, tatillerini geçirecekleri yerlerdeki, siyasi şiddet hadiselerine olabildiğince duyarlı olmakta ve siyasi şiddet hadiselerinin artış göstererek devam ettiği alanlara karşı seyahat gerçekleştirmekten kaçınmaktadırlar (Neumayer, 2004).

Yerkürenin herhangi bir yerine ziyaret gerçekleştiren turistin temel gereksinimlerinden bir tanesi olan şahsi güvelik algısı, turistin gideceği bölgede bulunabilecek seyahat riskinde tatilin iptal edilmesine veya tatil planlarının başka yerlere doğru yapılmasına neden olmaktadır (Öztürk ve Şimşek, 2013).

\section{Suriye ve Terörün Oluşturduğu Tahribat}

Suriye'de 1980 senesinde Halep, Humus ve Hama' da hükümet, muhalif kuvvetlere karşı aşırı zarar vermiştir. Suriye'nin kültürel miras değerleri olan camiler, kiliseler, evler yok edilmiş, yaklaşık 10.000 kişi ise öldürülmüştür (Cleveland, 2008: 441-451). 2011 senesinde Dera'da başlayan halk hareketleri 2019 senesinde hala devam eden bir iç savaşa dönüşmüş bulunmaktadır. Ülkede baş gösteren iç savaş nedeniyle 'Suriye 'nin Dünya Kültürel Miras Alanlarl”' savaş alanları halini almıştır (Durmaz, 2019: 4). Suriye'nin kültürel miras alanlar1; 'Kuzey Suriye eski köyleri, Busra Antik kenti, Halep Antik Kenti, Şam Antik kenti, Şövalyeler Kalesi, Palmira Sit Alanı', UNESCO Dünya Miras Listesi'nde yer almaktadır. İç savaş devam ederken ekonomik ve siyasal nedenlerden ötürü kültürel miras alanları uluslararası sözleşmelere uyulmayıp, ihlal edilip tahrip edilmektedir. Suriye'deki yerleşim alanları, hastaneler, sivil binalar, dini, tarihi, bilim, sanat, eğitim, yardım amaçlı yapılar askeri hedef olmaktadır (Durmaz, 2019: 4).

Suriye, semavi dinlerin ortaya çıktığı, farklı inançların görüldügü çok zengin bir coğrafya üzerinde bulunmaktadır. Dolayısı ile türlü tapınakları, ibadethaneleri ve dini merkezleri yapısında barındırmaktadır. Fakat bu zenginlik tarih boyunca harpler sebebi ile yağmalamaya ve tahribata maruz kalmıştır (Durmaz, 2019: 47). Bilhassa son senelerde silahlı çatışmaların gerçekleştiği ve devlet otoritesinin zayıflayıp kontrolün kaybolduğu yerlerde arkeolojik alanlara çok büyük çapta zarar verilmiştir. Hatta ekonomik nedenlerden dolayı da yerli halk tarafından eserlerin talan edildiği görülmektedir. Suriye'de meydana gelen tahribatın sebepleri içerisinde ekonomik ve dinsel nedenler gösterilebilmektedir (Durmaz, 2019: 48). Suriye' deki iç savaştan (2011 senesinden bu yana kadar) yaklaşık 3.000.000 kişi Türkiye' ye, toplamda 6.000.000 kişi göç etmiştir. 6 dünya mirası alanı tehlike altındaki miras alanları listesine alınmıştır. Tarihi yapılar ve çevreler, müzelerdeki nesneler ve arşivler zarara uğramıştır (Fidan ve Ünal, 2016: 479). 2011 yılında başlayan Suriye'de güvenlik sorunları nedeniyle başlayan, gerek ülke içine, gerekse ülke dışına göçe neden olan çatışma ortamı hedefli ve genel yıkımla, kültür mirasının da çok büyük oranlarda zarar görmesine sebebiyet vermiştir (Fidan ve Ünal, 2016: 482). Suriye'deki UNESCO Dünya Mirası listesinde bulunan alanların, hafif silahlar, roketler ve tanklar sebebiyle hasar gördüğ̈̈ bilinmektedir. UNESCO Dünya Mirası 
Listesi'nde yer alan Medine Kapalı Çarşısı, Ortadoğu'nun en iyi muhafaza edilmiş kapalı çarşıları içerisinde gösterilmekteyken yapıda meydana gelen yangında yüzlerce dükkân yanıp, kül olmuştur (Fidan ve Ünal, 2016: 483).

Savaşlar yıkımlara sebebiyet vermektedir. Çatışma alanlarında gerek seçici, gerek ise genel yıkımın hedefi olan kültür mirası ile ilgili hasarın gün geçtikçe değişmesi sebebiyle yıkımın gerçek boyutlarını belirlemek de pek mümkün olamamaktadır (UNESCO, 2016). Çatışmalar esnasında kasıtlı olarak yıkım ve kültürel varlıkların/değerlerin yağmalanmasıyla kişilerin ve grupların kimliğini yok etmek, çevreyle olan bağlantıları kesmek ve bir topluluk olarak onları bir bütün yapan bağları zedelemek amaç edinmektedir. Savaş ilan eden taraflar toplumları tarihe bağlayan eserleri, dokümanları ortadan kaldırmayı, geçmişleriyle olan bağlarını ve tarihlerini tamamıyla yok etmeyi arzu etmektedirler (Fidan ve Ünal, 2016: 480).

\section{Irak’ın Kültürel Mirasları Tehditler İle Karşı Karşıya}

1991 senesi Körfez Savaşı esnasında Irak sınırları içerisinde olan pek çok sayıda Mezopotamya (Akad, Asur, Babil, Sümer...) örenyeri, bölgesel müzelerle yüz binden çok tarihsel parçanın olduğu Bağdat'taki Irak Ulusal Müzesi, yöresel müzeler, türbeler, külliyeler, saraylar, bazı medreseler küçük veya büyük çapta tahribata uğramış bulunmaktadır. Ardından önüne geçilmesi zor talan ve yağmalama başlamıştır. Büyük müzayedelerde Mezopotamya kalıntıları alınıp, satılmıştır. Benzeri bir tehlike şu anda da yaşanmaktadır. Irak'ta bulunan insanlar, doğal yaşam ve kültürel miras değerleri tehlike altında olmaktadır. Tankların, konvoyların, füzelerin, uçakların meydana getirdiği titreşim, mermi başlıklarında bulunan seyreltilmiş uranyum, mermiler, bombalar, füzeler, tank atışları, siper kazmalar, sadece insanı ve doğayı değil, toprak altındaki ve toprak üzerindeki birçok kültürel mirası da tehdit etmektedir. Merkezi müzeler, yöresel müzeler, örenyerleri, oldukça önem taşıyan tarihi sivil yapılar, camiler, kiliseler, manastırlar, türbeler, tarihsel inanç yapıları, tarihi su

yapılar zarar görecektir (http://www.festtravel.com/irak-ta-olaganustu-bir-kulturel-miras-tehditaltinda).

Tehdit altında bulunan başlıca örenyerleri ve yapılar şu şekilde sıralanabilmektedir:

- $\quad$ Babil, Erbil, Ninova, Kerkük, Nemrud, Ur, Uruk, Hatra, Hadita örenyerleri.

- Tak Kisra'daki "Ctesiphon" milattan sonra 4. yüzy1la tarihlenen en büyük eski kemer.

- Musul, Erbil, Bağdat, Telefar, Kerkük, Kerbela, Necef, Samarra, Sancar'daki İslam yapılar.

- Bağdat'ta bulunan ünlü Ulusal Müze.

- Erbil, Kerkük, Nasiriye, Kut, Duhok, Musul, Süleymaniye'deki yöresel müzeler.

- Musul'daki Süryani Ortodoks Kilisesi, Kerkük’teki Meryem Ana Kilisesi, Bağdat'taki Keldani Kilisesi, Meryem Ana Kilisesi, Süryani Katolik Kilisesi.

- Kerbela Türbesi ve Necef Türbesi.

- Bağdat yapıları: İmam-1 Azam Ebu Hanife Külliyesi, Abdülkadir Geylani Külliyesi, Mustansiriye Medresesi, Mercan Medresesi (http://www.festtravel.com/irak-ta-olaganustu-birkulturel-miras-tehdit-altinda).

\section{Irak ve Suriye'de Tarih Tehlike Altında}

Kuzey Irak'ın ve Suriye'nin Kültürel zenginliklerini takip etmek antikacılar ve arkeologlar için iç dağlayan bir sorumluluk haline gelmiştir. DAEŞ'in Kuzey Irak'a ilerlemesinden sonra yağmalanan ve tahrip edilen yapıların listesi günden güne artış göstermiştir. Bölgede bulunan gruplar camiler, kiliseler, mezarlar, tapınaklar, heykeller gibi putperestlik olarak görmüş oldukları bütün şeyleri yok etmektedirler. Notre Dame Üniversitesi’nde Cadida Moss adlı profesör konuyla ilgili olarak, “ $B u$ 
bölge, tarihin sayfalarına geçmiş bütün büyük imparatorlukların merkezi olmuştur, burada bahsettiğimiz şey art arda gelen nesillerin tek bir yerde toplanmış olan ve tümüyle yok edilen tarihi" söylemini ifade etmiştir (Evrensel Gazetesi, 2020). Savaşın sürdüğü son 3 yılda, uluslararası gruplar binlerce kişinin hayatını kaybettiği bir çatışmaya müdahale etme amacıyla beceri ve güçlerinin son raddesine kadar gelmişlerdir. Birçok olayda, tarihi alanların güvenliği, kültürel miraslarını muhafaza etmek için büyük risk alan yerli halka bırakılmıştır. Bazı uzmanlara göre Suriye'nin en büyük şehri ve en büyük tahrip antik ticaret merkezi olan Halep'te 17. yüzyıldan kalma dükkânların yer aldığı, görkemli bir labirenti andıran Merkez Çarşısı'nın büyük bir bölümü, alevler içerisinde kalmıştır. Şehrin ticaret merkezi konumunda olan bu bölge, insanlarının Ortaçağ zamanlarından bu yana nasıl yaşamını sürdürdügünü anlama açısından olabildiğince önem arz etmekteydi. Hükümet güçleri ve onların karşıtları arasında ortaya çıkan çatışmalar Suriye'nin en eski camilerinden bir tanesi olan ve kütüphane arşivinde değerli binlerce el yazması olan Halep Camii'ni tahrip etmiş bulunmaktadır. Binlerce sene ayakta duran caminin minaresi de devrilmiştir. Kaya çıkıntılarının üzerine yapılmış, dünyanın en eski kale ve kazı alanlarından bir tanesi olan Halep'in geleneksel tasarıma göre inşa edilmiş kalesi de hedeflerin arasında yer almaktaydı. Bu yap1, hükümet güçleri tarafindan üs bölgesi olarak değerlendirildi ve roketler saldırıları sonucu vurulmuştur. Savaş daha güney kesimlerde Ortaçağ mühendisliğinin harikası olan, aynı anda da Hristiyanlık ve İslam kültürünü kesişme noktasını simgeleyen, dünyanın en büyük ve en iyi muhafaza edilmiş Haçlı kalelerinden bir tanesi olan 'Crac des Chevaliers"'e de zarar vermiştir. Halep'in tarihsel bölgeleri de, bunlara benzeyen biçimlerde, hükümetin isyancı bölgeleri bombalaması ile tahrip edilmiştir (Evrensel Gazetesi, 2020).

En çok hasar alan yerlerden bir tanesi ise Batı Suriye'de yer alan sıralı sütunları ve ünlü mozaikleriyle dünyanın en büyük ve en iyi biçimde muhafaza edilmiş Roma ve Bizans yerleşim alanlarından olan Epemiye olmaktadır. DAEŞ ve diğer gruplar, putperestlik ve şirki cezalandırma düşüncesi ile hareket etmektedirler. Bunlara bağlı olarak, Sufi ve Şii bölgelerini, Babil ve Asurya'dan kalma Mezopotamya'ya ait yapıtları, şairlerin heykellerini, dar görüşlerinin dışında kalan Sünni ibadethanelere saldırılar düzenlemişlerdir (Evrensel Gazetesi, 2020).

Kuzey Irak'taki Musul'da, militanlar ufak Sufi ve Şii ibadethanelerine, mezarlarına ve camilerine de saldırdı. Londra'da yaşayan Iraklı Arkeolog Lamia Al Gailani Werr'in iddiasına göre, Osmanlı döneminden kalma binalara zarar verdiler. Hıristiyan ve Êzidi topluluklara işkence ettikleri yetmiyormuş gibi, St. Ephrem Katedralindeki haçı da aldı ve Kutsal Bakire Meryem'in heykeline zarar verdi. En kayda değer kültürel zararın, Haziran ayında tahrip edilen ve içerisinde hikayesi üç semavi dinin de parçası olan Hz. Yunus'un mezarının olduğuna inanılan camide meydana geldiği söylenebilir. Musul'da, militanlar küçük Şii ve Sufi ibadethanelerine, camilerine ve mezarlarına da saldırmışlardır. Londra'da hayatını sürdüren Iraklı arkeolog Lamia Al Gailani Werr'in iddia ettiğine göre, Osmanlı devrinden kalma yapılara zarar vermişlerdir. Ėzidi ve Hristiyan topluluklara işkence ettikleri yetmezmiş gibi, St. Ephrem Katedrali'nde bulunan haçı da almışlar ve Kutsal Bakire Meryem'in de heykeline zarar vermişlerdir. En önemli kültürel tahriplerden bir tanesinin, içinde Hazreti Yunus'un mezarının olduğuna inanılan camide ortaya çıktığı söylenebilmektedir (Evrensel Gazetesi, 2020). 
Tablo 1. 1990 Sonrası Savaş, Silahlı Çatışma Ve Çatışmaların Tarihi Çevre Üzerindeki Zararları Tablosu

\begin{tabular}{|c|c|l|}
\hline Tarih & Yer & \multicolumn{1}{c|}{ Etki } \\
\hline 1991 ve 2003 & Irak & $\begin{array}{l}\text { Savaş - 4 milyon Iraklı Suriye ve Ürdün'e, 500 bin Iraklı ise Türkiye, } \\
\text { Bahreyn gibi ülkelere sığınmıştır. Dünya miras alanları tehlikededir. Ur } \\
\text { şehri, Ctesiphon kemeri çatlamıştır. Musul'da 10. Yüzyıldan kalma bir cami } \\
\text { kismen yıkılmış, Tell al-Lahm ve Tell el-Obeid arkeolojik alanları hasar } \\
\text { görmüştür. Musul Müzesi, Bağdat Güzel Sanatlar Galerisi yağmalanmıştır. }\end{array}$ \\
\hline $\begin{array}{c}\text { 2011-devam } \\
\text { etmekte }\end{array}$ & Suriye & $\begin{array}{l}\text { İç savaş - Yaklaşık 3 milyon kişi Türkiye'ye, toplamda 6 milyon insan göç } \\
\text { etmiştir. 6 Dünya mirası alanı tehlike altındaki miras alanları listesine } \\
\text { alınmıştır. Tarihi çevreler, tarihi yapılar ve müzelerdeki objeler ve arşivler } \\
\text { zarar görmüştür. }\end{array}$ \\
\hline
\end{tabular}

Kaynak: Fidan ve Ünal, 2016: 479.

DAEŞ'in 2014 yılının temmuz ayından bu yana Irak ve Suriye'de yıkıma uğrattığı tarihi alanlar şunlardır (https://arkeofili.com/isidin-zarar-verdigi-10-kulturel-miras-alani/):

- Hatra (Irak)

- Ninova (Irak)

- Musul Müzesi ve Kütüphaneler (Irak)

- Nimrud (Irak)

- Horsabad (Irak)

- Hz. Yunus Türbesi (Irak)

- İmam Dur Türbesi (Irak)

- Apamea (Suriye)

- Duro - Europos (Suriye)

- Mari (Suriye)

\section{Metot}

Araştırmaın yöntemi nitel araştırma yöntemi olmaktadır. Bu çalışmada doküman analizi tekniği kullanılmıştır. Araştırmanın evreni; Ortadoğu Bölgesi, örneklem ise; Irak ve Suriye ülkeleridir. Veri toplama sürecinde; Pek çok Kitap, dergi yazıları, gazete haberleri, internet kaynakları, makale, tez, bildiri ve benzeri kaynaklardan faydalanılmaya çalışılmıştır. İnternet sayfalarında bulunan, ilgili haberlere değinilmiştir. Kişilerin Irak ve Suriye'deki terör olaylarına, iç savaşa ve önemli yapılara verilen zararın değerlendirilmesi hakkında görüşleri ifade edilmiştir. Bu araştırmada nitel veri toplama aracı ve analizi doküman analizi tekniğidir. Belge çözümlemesi araştırılması maksut olay ve olgu üzerine malumat barındıran yazılı gereçlerin analiz edilmesini kapsamı altına almaktadır. Belge çözümlemesi nitel araştırmada sadece kendisi bilgi edinme metodu olabileceği gibi başka bilgi edinme metotlarıyla bir arada kullanılması mümkündür (Șimșek, 2009: 42). Veri analizi sürecinde ise toplanan bilgiler titizlikle ve tarafsız bir şekilde analiz edilmiştir. 


\section{Bulgular}

Yüzlerce cami saldırıların hedef noktası olmuştur. Irak'ın başkenti Bağdat'ta Osmanlı, Abbasi ve Emevi devirlerinde yapılmış yüzlerce dergâh, medrese ve camii kullanılamaz durumu gelmiş bulunmaktadır. O zamanlardan sonra da hiçbir camide ciddi yenileme çalışması gerçekleştirilememiştir. Felluce'deki Hulafa el Raşid Camii, Huzistan Eyaletindeki Seyyedoşada Camii, Nasıriye'deki Babil İmparatorluğu'ndan kalma tapınak, Bağdat'ın en meşhur camilerinden bir tanesi olan Ebu Hanife Camii Amerika Birleşik Devletleri askerlerinin ağır silahlarının mermileri ile hasar görmüş ve yıkıma uğramıştır (Yeni Akit Gazetesi, 2020).

Musul artık hayalet şehir görünümüne bürünmüştür. Amerika Birleşik Devletleri, DEAŞ’I bölgeden temizleme gerekçesi ile operasyon gerçekleștirmiştir. O alanlardan biri de Musul olmaktadır. Amerika Birleşik Devletleri öncülügündeki koalisyon güçleri dokuz ay boyunca tarihi şehri bombalamıştır. Şehirde 40.000 kişi hayatını kaybetmiş, 126.000 aile evlerinden olmuştur. Birleşmiş Milletlere göre 1.000 .000 sivil şehri terk etmiştir. 8.475 ev yıkılmış, kamu binalarının da ilave edilmesi ile bu sayı 10.000'i aşmıştır. Şehirdeki İslam ve Türk izleri de kaybolmuştur. Osmanlı eserlerinin neredeyse tamamına yakını tahribata uğramıştır. Tarihi kervansaray, İmam Avneddin Camii, Hidırellez Cami, Yunus Nebi Camii, El Nuri Camii, Musul'un simgesi Hadba Saat Kulesi, kullanılamaz durumu gelmiştir. Gelecek nesillerin İslam uygarlığının bu simge eserlerinde artık namaz kılma ve mimari güzelliklerini izleme olanağı bulamayacağını ifade etmek doğru olacaktır (Yeni Akit Gazetesi, 2020).

600.000'den fazla kişinin hayatını kaybettiği tahmin edilen Suriye iç savaşının bir kurbanı da ülkenin kültürel varlıkları olmaktadır. Rejim güçleri ve muhalifler arasında gerçekleşen çatışmalarda pek çok tarihi eser tahrip olmuştur. İç savaşın başladığı 2011 senesi Mart ayından bu zamana değin 1.000'den fazla cami yıkılmış veya zarara uğramıştır. Camilerin yanı sıra olarak pek çok sayıda çarşı, sivil mimarlık eseri tarihi ev, müze, türbe ve medrese harabeye dönmüştür. Bunlar içerisinde en çok göze çarpan ise Halep Kenti'nde bulunan Emevi Camii olmaktadır. 8.yy.da yapılan caminin 13.yy.da tekrardan yapılan minaresi saldırılar nedeniyle kullanılamaz duruma gelmiştir. Halep Kenti'nde bombardımana tutulan bir başka cami ise Hz. Zekeriya Camii olmaktadır. İçinde Hz. Zekeriya'nın türbesi bulunuyordu. Ayrıca Hz. Muhammed'in dişi ve Sakal-1 Şerifi' de bulunmaktaydı (Yeni Akit Gazetesi, 2020).

Rakka Şehrinden gelen görüntüler, gerçekleştirilen bombalamanın büyüklügünü gözler önüne sermektedir. Yüzlerce yap1 yıkılır iken, hava görüntüleri olan biten her șeyi bütün çıplaklığıyla anlatmaya yetmektedir. Amerika Birleșik Devletleri hava kuvvetleriyle DEAȘ ve PKK'nın üs olarak kullandığ1 gerekçesi ile camiler bombardımana tutulmuş ve geriye sadece taş yığınları kalmış bulunmaktadır. Şehrin tekrardan yapılanması, tarihi camilerin restore etme kaidelerine göre ihya edilmesiyse yakın gelecekte pek de mümkün görünmemektedir. Suriye'nin UNESCO dünya mirası listesinde yer alan 6 alanı Bosra Antik Kenti, Crac Des Chevaliers, Qal'at Salah El-Din Kaleleri, Şam Antik Kenti, Halep Antik Kenti ile 'çölün gelini" ' lakaplı antik kent Palmira; hafif silahlar, roket, ve tank sebebi ile ağır hasar almıştır. Halep Şehrinin Ortaçağ zamanından kalan çarşıları da yok olmuştur (Yeni Akit Gazetesi, 2020). DAEŞ terör örgütü, Suriye'de ele geçirdiği Palmira antik şehrinde olan Tetrapylon anıtını yıkmıștır. Yine DAEŞ tarafından 2.000 senelik tapınak, bir kemer ve kule mezarlar da y1kılmıştır (https://www.bbc.com/turkce/haberler-dunya-38688672, Erişim Tarihi: 16.04.2020). Palmira antik kentinin DAEŞ terör örgütü tarafından ele geçirilmesi ise bir görgü tanığının " $B u$ medeniyetin düşüşüdür. Insanlık, medeni toplum; barbarlı̆̆a karşı savaşını kaybetti. Tüm umudumu yitirdim. Palmira'yı asla unutmayacă̆ız" sözleri ile aktarılmaktadır (Yenen, 2016: 170). 
Amerika Birleşik Devletleri, İsrail, Rusya, İran, İngiltere ve Fransa Esed ve Irak rejimleriyle işbirliği yaparak binlerce senelik tarihi şehirleri harita üzerinden silmiştir. Her tarafında Osmanlı ve Selçuklu izleri taşıyan Kerkük ve Musul, uygarlıkların ortak noktası olan Halep, Halid bin Velid'in ve onlarca sahabenin medfun olduğu 2.000 senelik y1llık Humus, Türklerin Anadolu'ya ilk giriş kapısı olma özelliği taşıyan Rakka, Zennubya' dan Emevi'lere ve Osmanlı Devleti'ne ilişkin pek çok tarihi mirasın bulunduğu Hama ve Tedmur, Kerkük, Dera, El Bab son 30 senelik yağma devrinin kurbanı merkezler arasında yerlerini almaktadır. Aşuri, Sasani, Makduni, Keldani, Babil, Emevi, Abbasi, Roma, Zengi, Eyyubi, Osmanlı ve Selçuklu devirlerinden sayısız izler taşıyan şehirler bütün ziynetleriyle beraber enkaz haline getirilmiştir. Onlarca tarihi cami, kilise, köprü, kervansaray, kale, ilkel tapınak içinde hayatını sürdüren insanlarla beraber bombardımana tutuldu. Enkaz haline gelen mekânlarda 3.000.000 kişi öldürülür iken, 7.000.000 kişi ise yaralanmıştır. Onlarca uygarlık ve ortak hafızayı silme maksatlı 30 senelik istila ve yağma süreci içerisinde 23.000 .000 kişi hayatını devam ettirdiği mekânlardan sürülmüştür (Yeni Akit Gazetesi, 2020). Irak ve Suriye' de yaşanan çatışmalar, iç savaş, işkence gibi durumlar tüm dünyada gündem yer alan konular arasında gelmektedir. Bu olayların altında dini, psikolojik ve sosyal problemlerin olduğu tahmin edilebilmektedir. Özellikle İslam dinine mensup olan kişilere karşı İnsanlarda bir önyargı oluşmaktadır. Siyasi anlaşmazlıkların görüldügü Ortadoğu Bölgesi'nde birçok çıkar çatışmalarının olduğu ise yadsınamaz bir gerçek olmaktadır. Terörün yoğun olarak yaşandığı Irak ve Suriye'de insanlar başka ülkelere göç etmektedirler. Bu ülkelerin insanları gittikleri ülkelerde birtakım suçlar (kapkaç, hırsızlık, yaralama, taciz, tecavüz, kundaklama vb. gibi) işleyebilmektedir. $\mathrm{Bu}$ şekilde yaşanan olaylar siyasi olumsuzlukların gerçekleşmesine neden olmaktadır. Ülkelerin bazıları sınır kapılarını kapatarak mülteci kabul etmemektedir. Önemli yapılar (dini, tarihi, kültürel vs.) tüm dünya ülkelerinin önem verdiği değerler arasında gelmektedir. Bu yapılar terör örgütleri tarafindan tahrip edilmektedir. Ülkeler, Irak ve Suriye'ye hava saldırıları düzenlemektedir. Bölgede terörizmin sona ermesi için gerek havadan gerek ise karadan operasyonlar gerçekleştirilmektedir. Ortadoğu Bölgesi'nde terörün durdurulması ve önemli yapıların korunması amaçlı daha fazla ve etkili planlamalar ve faaliyetler siyasi otoritelerce gerçekleştirilmesi gerekmektedir.

Amerika Birleşik Devletleri işgali ile yıkıma uğrayan Irak’ta hem Amerika Birleşik Devletleri güçleri hem de DEAŞ terör örgütü tarafindan dini ve tarihi mekânlar kasıtll bir biçimde tahrip edilmiştir. Bunların başında da Amerika Birleşik Devletleri işgali esnasındaki çatışmalarda hasar alan Necef Şehrindeki Hazreti Ali Türbesi gelmektedir (https://www.bik.gov.tr/notre-dame-islam-ulkelerindetahrip-edilen-eserleri-hatirlatti/).

Tarihi eser mafyası; M.Ö. 2000'li senelere kadar uzanan Mezopotamya eserlerini barındıran ulusal müze en başta olmak üzere Irak en kıymeti müzeleri yağmalanmıştır. Batı resminin en değerli koleksiyonları tarihi eser kaçakçıları aracılığıyla Amerika Birleşik Devletleri ve İngiltere'ye götürülüp satılmıştır. Araştırmacılar işgal esnasında Irak'tan 15.000 tarihi eser kaçırıldığını belirtmektedirler. 2006 senesinde bu eserlerin bir kısmı, Amerika Birleşik Devletleri'nde Müzayede evlerinde ortaya çıkmıştır. Amerika Birleşik Devletleri şu ana kadar Irak'a 1.200 eser iade etmiş bulunmaktadır. Tarihi eser mafyasının son 20 sene içerisinde en fazla aktif olduğu alanlar, hiç kuşkusuz Suriye ve Irak olmaktadır (Yeni Akit Gazetesi, 2020).

Irak ve Suriye'deki kültürel değerlere yönelik gerçekleştirilen tahrip ve temel sorunlar şöyle siralanabilmektedir (UNESCO, 2016): 
- 'Tahribatın Belgelenmesi ve Güvenilir Bilgi Akışı'”: Çatışma yerlerinde gerek seçici, gerek ise genel y1kımın hedefi halinde bulunan kültürel mirasa ilişkin hasarın gün geçtikçe değişim göstermesi sebebi ile yıkımın gerçek boyutunu saptamak pek mümkün olamamaktadır. UNESCO, 2011 senesinden sonra bölgedeki güvenlik problemi sebebiyle Suriye’ye Reaktif İzleme Misyonu kapsamı altında uzman gönderememiştir. $\mathrm{Bu}$ sebeple, bilhassa dünya miras alanlarında gerçekleşen hasarın boyutu hakkındaki bilgilerin bir bölümü yerel uzmanlardan sağlanabilmekte veya uzaktan izleme yöntemleriyle (UNOSAT) tespit edilebilmektedir. Bilgi akışı dâhilindeki bu problemlere bağlı olarak, kültürel mirasa yönelik tahribatın nedeni, zamanı, konumu ve boyutuna ilişkin farklı kaynaklardan edinilen bilgilerde çelişkiler yaşanabilmektedir.

- 'Dünya Miras Alanlarında Askeri Amaçlı Kullanım ve Kaçak Yapılaşma': Bilhassa uygun fiziksel ortamın oluşturulması sebebiyle arkeolojik yerlere konuşlanan askeri üslerin düşman tarafın silahlı ve bombalı saldırıların maruz bırakılması tahribatı artırmaktadır. Diğer taraftan yönetimdeki boşluk bu uygun fiziki yerlerde kaçak yapılaşmanın da meydana gelmesine/artmasına sebep olmaktadir.

- Kaçak Kazılar ve Yeni Ortaya Çıkan Arkeolojik Alanlar: Bilhassa tahrip etme gücü yüksek patlamalar neticesinde meydana gelen yeni arkeolojik alanlarla mevcut arkeolojik alanlarda kaçak yapılan kazılar neticesi meydana gelen yeni bölümlerin belgelenmesi mümkün olamamakta, arkeolojik bulgu ve bu alan için mühim değere sahip veriler ihtiva eden tüm ortam zarar görmektedir. Kaçak kazılar sonucu ortaya çıkarılan eserlerin de yasa dışı yollar ile ticaretinin gerçekleştirildiği göze çarpmaktadır.

- 'Yasa Dışı Eski Eser Ticareti ve Ele Geçirilen Eserlerin Korunması Sorunu'”: Çatışma alanlarında kültür değerlerinin yasa dışı yollar ile ticareti bilhassa çatışma ve terör için mühim bir kaynak oluşturduğu bilinmektedir. Bilhassa Irak ve Suriye sınır güvenliğinde yaşanan çatışmalar esnasında bu alanlarda tek taraflı meydana gelen güvenlik açı̆̆ı, kültür değerlerinin yasa dış1 ticaretinin artmasina sebep olmuştur.

- Tehlike Altındaki Kültür Mirasının Korunmasında Öncelik Algısı: Takip edilmesinin başka miras mevzularına göre kolaylığı, neden-sonuç ilişkisinin belirgin olması gibi sebeplerden dolayı bilhassa yasa dışı eski eser trafiği, çatışma alanlarında kültürel mirasın muhafaza edilmesi hususunda genelde en mühim gündemi oluşturmakta ve temel endişe duyma konusu gibi görülebilmektedir. Negatif tesirlerinin nispeten uzun zaman dilimi içerisinde meydana gelmesi, tahribat takibi problemi ve benzeri sebeplerden dolayı geleneksel yapılar, kırsal miras, bilhassa da özgün kullanıcıların kaybı ile kesintiye uğrayan somut ve somut olmayan miras ilişkisindeki uzun süreçte meydana gelebilecek daha kalıcı problemlerin ikinci planda kalmasına sebep olmaktadır.

- Propaganda Yakıtı Olarak Medya'da Kültür Mirasının Kullanımı: Çatışma alanlarında silahlı güçlerin mimari yapıtlar, müzeler gibi miras varlıklarını zarar verme görüntüleri sosyal medya ortamında çok geniş yankı bulmaktadır. Mühim bir kısmı zararı veren (tahribatı gerçekleştiren) grup tarafindan paylaşılan bu görüntüler için bir denetim söz konusu olmamaktadır. Bu hal tahribatın çok geniş kesimler tarafindan öğrenilmesine ve tepki gösterilmesine imkân vermiş olsa bile, kültürel mirasın propaganda malzemesi olarak kullanılması ve bu maksatla tahrip edilmesinin yaygınlık göstermesine zemin hazırlamış olacaktır. 
Irak ile Suriye'deki yakın ve uzak dönem tehditleri şöyle sıralanabilmektedir (UNESCO, 2016):

- Kültürel mirasının muhafaza edilmesine yönelik yasaların uygulanmasına ilişkin problemler ve bilhassa çatışma halinde kültürel mirasının muhafaza edilmesine ilişkin enternasyonal kararların ülkelerin yasal mevzuatlarının bir bölümü olmaması sebebiyle bağlayıcı olmaması.

- Nüfusun büyük bir kesiminin savaş esnasında güvenlik sebebiyle ülke dışarısına gitmesi sebebi ilen tarihi alanların boşalması, geri dönme zamanında da özgün kullanıcıların aynı bölgelere tekrardan geri varamama riski.

- Savaş esnasında ve hemen akabinde muhafaza etme konusunda çalışan kurumların yaşamış olduğu veya yaşayacağı işlerlik problemine bağlı olarak ortaya çıkacak boşlukta plansız yerleşimin somut kültürel miras alanlarını tehdit etmesi.

- Ekonomik kriz, tasarruf yapma önlemleri sebebi ile kültür mirasının muhafaza edilmesine yönelik bütçede kısıtlamalara gidilmesi; kısıtlı olan bütçenin kullanılmasındaysa, öncelik belirleme ve derecelendirme problemi yaşanması.

- Ölüm, göç etme ve benzeri sebeplerle kültür mirasının muhafaza edilmesi konusunda çalışan yöresel uzmanlarının sayılarının günden güne azalması.

- Muhafaza etmede değerlendirilecek teknolojik malzeme ve ekipmanın pahalı olması ve uzman uygulayıc1 sayılarının yeterli seviyede olmaması (UNESCO, 2016).

\section{Tartışma ve Sonuç}

Her şeyden önce Ortadoğu Bölgesi yaşananlar insanlık suçu olmaktadır. Irak ve Suriye'de toprak bütünlügü büyük risk altında olmaktadır. Toprakları üzerinde terör saldırıları, iç savaş, çatışmalar, siyasi istikrarsızlık, can ve mal kayıpları, türlü işkenceler ve ülke içerisinden dişarıya göçler yaşanmaktadır. Bu bölgelerde önemli yapıların (dini, tarihi, kültürel ve benzeri yapılar) iç savaş ve terör olayları saldırıları esnasında tahribata uğramaktadır. DAEŞ ve benzeri terör örgütleri özellikle kasten bu yapılara zarar vermektedir. Bu kapsamda gerçekleşen olaylar dünya kamuoyunda geniş yankı bulmaktadır. Siyasi otoritelerin gündeminde Ortadoğu Bölgesi ve terör olaylarının daha çok yer bulması sağlanmalıdır. Siyasi gelişmeler ve ortaya çıkabilecek olası olumsuz durumlar yakın ülkelere de etki gösterebilmektedir.

Müslüman kimselere karşı önyargılı davranışların görüldüğü göze çarpmaktadır. Bu durumun daha çok Irak ve Suriye'de terör saldırıları gerçekleştiren terör örgütlerinin sebep olduğunu söylemek mümkün olmaktadır. Bu kişiler din kisvesi altında amaçlarını gerçekleştirmektedirler. Toplumun kanayan yarası olan terörün asıl nedenleri, amaçları, stratejileri hakkında başta Irak ve Suriye halkı olmak üzere bütün insanlar bilinçlendirilmelidir. Tarihi eserlerin yağmalanmasına izin verilmemeli ve tahribata uğratılmasının önüne geçilmelidir.

Önemli yapılara verilen zararlar, tüm dünyanın ortak somut olmayan kültürel miraslarını hedef almaktadır. Terör örgütleri gerçekleştirecekleri/gerçekleştirdikleri saldırlar ile psikolojik bask1 yaparak sindirme, insanları yıldırma amaçları gütmektedir. Cana ve mala kastetmeyi, kültürel varlıklar1 yok etmeyi istemektedir.

Irak ve Suriye bölgelerinde gerçekleşen terör saldırılarının arkasında, bazı siyasi güçlerin olduğu tahmin edilmektedir. Yeraltı, yer üstü kaynaklarının sömürülmesi için bazı ülkeler ve terör örgütleri bu alanları bilerek veya bilmeyerek de tahrip ettiği öne sürülebilmektedir. 
Dünyada üzerinde görülen dini ve siyasi çatışmalar insanların algılarına olumsuz şekilde etki etmesine neden olmaktadır. Söz konusu olan ülkelerin imajları zedelenmektedir. Kültürel değerlerin yok olması, insanların da kendi öz benliğinden kopmasını ifade etmektedir. Kültürel mirasların muhafaza edilmesi hususunda öncelikle başta yerel halk olmak üzere herkesin sorumluluk bilincinde olması gerekmektedir. Yaşatılamayan kültürler, uygarlıkların çöküşünü yansıtmaktadır.

Ortadoğu Bölgesi’nde görülen iç savaşlar, karışıklıklar, çatışmalar, işkenceler insanları derinden etkilemektedir. Bölge içerisinde birçok terörist gruplar varlık göstermektedir. Pek çok tarihi, dini ve kültürel açıdan öneme sahip olan yapılar bu gruplar tarafindan tahrip edilmektedir. Irak ve Suriye'de de aynı durumlar geçerli olmaktadır. Buralardaki kültürel değerler ve tarihi eserler tahrip edilmekte veya yağmalanmaktadır. Bilhassa bölgede bulunan eski medeniyetlere ait olan eserlerin talan edildiği görülmektedir. Bu olayların Irak Savaşı'ndan sonra şiddetini ve etkinliğini artırarak gerçekleştiği öne sürülebilmektedir. Terör olayları karşısında siyasi otoriteler belirli bir karara varmak istemekte ama bu günümüzde pek de mümkün olmamaktadır. Öncelikli olarak Irak ve Suriye' de görülen siyasi belirsizlik nasıl giderilebilir, bunlar hakkında etkili planlama ve stratejilerin geliştirilmesi önem arz etmektedir. Birçok ülke iç savaş nedeniyle kendi ülkelerin kaçan mültecileri ülkesine kabul etmemektedir. Irak'a ve Suriye'ye gerçekleştirilen hava ve kara operasyonları sayesinde bir nebze olsun terörün önüne geçilmek istenmektedir.

Irak ve Suriye' de terör saldırıları sebebiyle tahrip edilmiş birçok cami, mescit, kilise, medrese, köprü, kervansaray, tarihi evler görülmesi mümkün olmaktadır. Irak ve Suriye yönetimi vatandaşlarına milli değerlerine sahip çıkma hususunda yeterli bilgi vermesi ve motivasyon sağlaması gerekmektedir. Durum böyle olmadığı takdirde ekonomik ve kültürel tahribatın önüne geçilmesi zor olmaktadır.

Terör ile mücadele konusunda bütün siyasi otoriteler ortak hareket etmediği sürece bu durumun sona erdirilmesi çok zor olacaktır ve uzun zaman alacaktır. Irak ile Suriye'deki insanlar, teröre ve iç karışıklığa karşı omuz omuza bir mücadele sergilemelidir. Unutmamak gerekir ki birlikten kuvvet doğmaktadır. Birlik ve bütünlügün olmadığ 1 yerler terör gruplarının odak noktaları olmaktadır. Bu araştırma sonucunda şu öneriler verilebilmektedir:

- Kültürel mirasın muhafaza edilmesine yönelik olarak acil müdahale etme planının yapılması, acil müdahale ekiplerinin oluşturulması ve bu oluşturulan ekiplere uluslararası uzman desteği verilmesi önem arz etmektedir.

- Risk yönetimi konusunda ilgili kurum ve kurum ve kuruluşlar ile işbirliği yapılmalı, oluşturulacak 'görev gücü' ile uzman personel tecrübelerinin yönlendirilmesi gerekmektedir.

- Birey ve kurumlar arasında haberleşme ve eşgüdüm sağlayacak araçlar oluşturulmalı ya da bu araçların oluşturulmasına destek verilmelidir.

- Bütün çalışmalar ve tedbir için uygulama planları gerçekleştirilmeli ve bütçe tahsisi yapılmalıdır.

- Çatışma sonrası muhafaza etmesi çalışmalarının denetimli bir şekilde uzman ekipler aracılığı ile yapılması sağlanmalıdır; ulusal yetkililer aracılığıyla gönüllü kişilere verilecek izinlerde hassasiyet gösterilmelidir ve bu 'gönüllü' ' çalışmalarının kesinlikle uzmanların denetimi altında gerçekleştirilmesi sağlanmalıdır (UNESCO, 2016). 


\section{Kaynakça}

Anson, C. (1999). Planning For Peace: The Role Of Tourism In The Aftermath Of Violence. Journal Of Travel Research, 38(1), 57-61.

Bal, İ. (2006). Terör, Terörizm ve Küresel Terörle Mücadelede Ulusal ve Bölgesel Deneyimler, Uluslararası Stratejik Araştırmalar Kurumu, USAK Yayınları, Güvenlik Serisi:1, Ankara.

Bozdemir, M. (1981). “Terör (mü) ve Terörizm (mi)?”, AÜ SBF Basın Yayın Yüksek Okulu Yıllığı, 6, 526.

Cleveland, W. L. (2008). Modern Ortadoğu Tarihi. İstanbul: Agora Kitaplığı.

Çakıcı, A. C., Benli, S., Üzülmez, M., ve Kaynak, M. (2015). Turizm ve Barış İlişsisi Üzerine Lisansüstü Turizm Öğrencilerinin Algısı. 16. Ulusal Turizm Kongresi. 12-15 Kasım 2015, Çanakkale/Türkiye. ss. 648-665, ISBN: 978-605-9189-27-9.

Durmaz, E. (2019). Savaşların Kültürel Miras Üzerindeki Etkisi: Suriye Örneği. Yüksek Lisans Tezi. Marmara Üniversitesi, Orta Doğu ve İslam Ülkeleri Araştırmaları Enstitüsü, İstanbul.

Emsen, Ö. S. ve Değer, M. K. (2004). Turizm üzerine terörizmin etkileri: 1984-2001 Türkiye deneyimi. Akdeniz University Faculty of Economics \& Administrative Sciences Faculty Journal / Akdeniz Üniversitesi İktisadi ve İdari Bilimler Fakültesi Dergisi, 4 (7), 67-83.

Evrensel Gazetesi (2020). Suriye ve Irak'ta Tarih Risk Altında. Erişim Adresi: https://www.evrensel.net/haber/94731/suriye-ve-irakta-tarih-risk-altinda, Erişim Tarihi: 14.04.2020.

Fidan, S. G. ve Ünal, Z. G. (2016). Güvenlik Sorunlarına Bağlı Gelişen Zorunlu Toplu Göçlerin Tarihi Çevre Üzerindeki Etkisi.

Güvenek, B. ve Alptekin, V. (2015). Turistlere Yönelik Terör Saldırılarının Turizme Etkisi: Türkiye Üzerine Ampirik Bir Çalışma. Selçuk Üniversitesi Sosyal Bilimler Meslek Yüksekokulu Dergisi, 17(1), 21-38.

Kaya, İ. (2005). Terörle Mücadele ve Uluslararası Hukuk, (1. Basım), Ankara: Usak Yayınları, S.1.

Kaynak, İ. H. (2010). İnanç Turizminin Medeniyetler Arası İşbirliğine Etkileri: Türkiye Örneği. Selçuk Üniversitesi Sosyal Bilimler Meslek Yüksekokulu Dergisi, 13(1-2), 119-126.

Kervankıran, İ. ve Eryılmaz, A. G. İnanç Turizmine Yönelik Ziyaretçi Algılarının Demografik Farklılıklar Açısından İncelenmesi: Konya Mevlana Müzesi Örneği. Akademik Bakı̧ Uluslararası Hakemli Sosyal Bilimler Dergisi, (59), 276-296.

Neumayer, E. (2004). The Impact Of Political Violence On Tourism Dynamic Cross-National Estimation. Journal Of Conflict Resolution, 48(2), 259-281.

Oktayer, N., Susam, N. ve Çak, M. (2007). Türkiye'de Turizm Ekonomisi. (1.Basım). İstanbul: İstanbul Ticaret Odasi.

Özerkmen, N. (2004). Terör, Terörizm ve Radikal İslamcı Terör, Ankara Üniversitesi, Dil ve Tarih-Coğrafya Fakültesi Dergisi, 44(2), 242-265.

Özgüç, N. (2011). Turizm Coğrafyası Özellikler Bölgeler, Çantay Kitabevi, İstanbul.

Öztürk, Y. ve Şimşek, E. (2013). Politik İstikrarsızlıkların Turistlerin Destinasyon Seçimine Etkisi Üzerine Bir Araştırma. Journal Of Tourism And Gastronomy Studies, 1(2), 1525.

Richards, G. (2007). Cultural Tourism: Global and Local Perspectives, Howard Press, New York, ABD.

Richter, L. K. (1986). Terrorism and Tourism as Logical Companions. Tourism Management, 7: 230-238.

Richter, L. K. Ve Waugh, W. L. (1983). Tourism Politics and Political Science: A Case of Not So Benign Neglect. Annals of Tourism Research, IO:3 13-3 15. 
Şener, Y. (2012). Terör ve Turizm Ilişskisi: Türkiye Üzerine Yansımalar. Yüksek Lisans Tezi. Düzce Üniversitesi, Sosyal Bilimler Enstitüsü, Düzce.

Şimşek, H. (2009). Eğitim Tarihi Araştırmalarında Yöntem Sorunu. Ankara Üniversitesi Eğitim Fakültesi Dergisi, 42 (1), 33-51.

UNESCO. (2016). Unesco Türkiye Milli Komisyonu, Somut Kültürel Miras İhtisas Komitesi, Çatışma Nedeniyle Tehlike Altında Bulunan Dünya Miras Alanları Alt Çalışma Grubu Raporu, "Suriye Ve Irak'ta Çatışma Nedeniyle Tehlike Altında Bulunan Kültür Mirası", http://www.unesco.org.tr/Content_Files/Content/Yayinlar/2016fr.pdf, Erişim Tarihi: 16.04.2020,

Usta, Ö. (2008). Turizm-Genel ve Yapısal Yaklaşım. Ankara, Detay Yayıncılık.

Ünsal, A. ve Keleş, R. (1982). Kent ve Siyasal Şiddet. Ankara Üniversitesi, Siyasal Bilgiler Fakültesi Yayınları: 507.

Yenen, İ. (2016). Yazılı Basında Yayımlanan Küresel Terör Haberleri Üzerine Sosyolojik Bir Çözümleme/A Sociological Analysis on Global Terror News Published in Print Press. Journal of History Culture and Art Research, 5(3), 152-177.

Yeni Akit Gazetesi (2020). İslam Şehirleri Yok Ediliyor. Erişim Adresi: https://www.yeniakit.com.tr/haber/islam-sehirleri-yok-ediliyor-388137.html, Erişim Tarihi: 16.04.2020.

https://arkeofili.com/isidin-zarar-verdigi-10-kulturel-miras-alani/, Erişim Tarihi: 01.06.2020.

https://www.bbc.com/turkce/haberler-dunya-38688672, Erişim Tarihi: 16.04.2020.

https://www.bik.gov.tr/notre-dame-islam-ulkelerinde-tahrip-edilen-eserleri-hatirlatti/, Erişim Tarihi: 18.04.2020.

http://www.festtravel.com/irak-ta-olaganustu-bir-kulturel-miras-tehdit-altinda, Erişim Tarihi: 14.04.2020. 